Volume 2, Nomor 1, February 2020, p. $49-54$

ISSN 2655-9951 (print), ISSN 2656-0062 (online)

\title{
Pengaruh polisakarida dalam panax ginseng untuk vaksinasi flu burung (H5N1)
}

\author{
Geri Indra Herlambang ${ }^{1 *}$; Putu Ristyaning Ayu Sangging ${ }^{2}$ \\ ${ }^{1,2}$ Fakultas Kedokteran Universitas Lampung \\ Email: geriindra@gmail.com
}

\begin{tabular}{|c|c|}
\hline ARTICLE INFO & ABSTRACT \\
\hline $\begin{array}{l}\text { *) corresponding author } \\
\text { Fakultas Kedokteran Universitas Lampung1 } \\
\text { Jl.Prof. Dr. Ir. Sumantri Brojonegoro No. 1, } \\
\text { Gedong Meneng, Kec. Rajabasa, Kota } \\
\text { Bandarlampung, } 35145 \text { Indonesia } \\
\text { Telp. } 082289551844\end{array}$ & $\begin{array}{l}\text { Avian Influenza disease is caused by an avian influenza virus infection } \\
\text { that became one of the biggest causes of death in the world. The } \\
\text { subtype of the virus present in Indonesia is the H5N1 virus. According } \\
\text { to the World Health Organization (WHO), in 2012, the outbreak of the } \\
\text { H5N1 subtype avian influenza virus was first reported in 1996, } \\
\text { Guangdong Province, South China, and spread to Indonesia since } \\
\text { 2003. The number of death from avian influenza outbreak (H5N1) in } \\
\text { Indonesia was recorded to be the highest in the world, with the number } \\
\text { of death was } 151 \text { of } 183 \text { people who positively infected with the virus. } \\
\text { The H5N1 virus can enter and infect humans when the body's immune } \\
\text { system of the person is low. Panax ginseng belongs to the Araliaceae } \\
\text { family, which contains several components, such as ginsenosides, } \\
\text { polyacetylenes, polyphenols, and polysaccharides. The Polysaccharides } \\
\text { in Panax ginseng have an immunomodulatory function that can } \\
\text { increase cytokine production and activate macrophages as an effort to } \\
\text { improve and increase the body's immune system. Therefore, } \\
\text { polysaccharides in Panax ginseng affect avian influenza vaccination } \\
\text { because it enhances the body's immune response. }\end{array}$ \\
\hline
\end{tabular}

This is an open access article under the CC-BY-SA license.

\section{PENDAHULUAN}

Virus Flu Burung adalah virus influenza tipe A yang menyebabkan suatu penyakit menular yaitu flu burung dan berasal dari family orthomyxoviridae. (Fauquet, 2005). Virus flu burung atau avian influenza (VAI) subtipe H5N1 yang sangat patogen, telah mewabah pada unggas di Indonesia sejak akhir 2003 (WHO, 2005).

Virus flu burung termasuk dalam virus RNA yang memiliki kemampuan bermutasi dengan cepat. Virus ini terbagi dalam beberapa subtipe berdasarkan kombinasi glikoprotein yang dimiliki yaitu 
antigen hemaglutinin (HA1-16) dan antigen neurominidase (NA1-9) (Janovie, 2014; Radji, 2006; Park, 2013).

Menurut WHO tahun 2012, wabah virus flu burung subtipe H5N1 pertama kali dilaporkan pada tahun 1996 di Provinsi Guangdong, Cina Selatan. Wabah virus ini kemudian menyebar dan menyebabkan kematian unggas di beberapa Negara seperti Laos, Jepang, Korea Selatan, dan Indonesia. Jumlah kasus kematian akibat wabah virus flu burung (H5N1) di Indonesia hingga 2012 tercatat paling tinggi di dunia yaitu dengan jumlah kematian mencapai 151 dari 183 orang yang positif terinfeksi virus tersebut (WHO, 2012; Janovie, 2014).

Virus A Influenza memiliki struktur antigen permukaan antara lain Hemaglutinin dan Neuroamidase. Penggolongan subtipe virus tersebut adalah atas dasar kandungan Hemaglutinin yang terdiri atas 16 subtipe dan atas dasar Neuroamidase yang terdiri atas 9 subtipe. Jenis yang menyerang Indonesia menurut pemerintah yang diumumkan oleh Ditjenak adalah subtipe H5N1 (Janovie, 2014; Ernawati, 2011).

Penularan atau transmisi dari virus influenza secara umum dapat terjadi melalui inhalasi, kontak langsung, ataupun kontak tidak langsung. Sebagian besar kasus infeksi HPAI pada manusia disebabkan penularan virus dari unggas ke manusia. Mutasi genetik virus avian influenza seringkali terjadi sesuai dengan kondisi dan lingkungan replikasinya. Mutasi gen ini tidak saja untuk mempertahankan diri akan tetapi juga dapat meningkatkan sifat patogenisitasnya (Radji, 2006).

Virus H5N1 di Indonesia sudah mencapai kondisi endemik dan berkembang menjadi kelompokkelompok genetik A, B, dan C dengan sebaran geografis yang bervariasi. Sub-kelompok A ditemukan di Jawa, Sulawesi Selatan, dan Timor Barat. Subkelompok B terisolasi dari Jawa, Flores, Bali dan Timor Barat, dan sub-kelompok C berasal dari isolat Sumatra dan Jawa (Smith, 2006).

Ketersediaan dan penggunaan vaksin yang efektif dapat menjadi suatu alat yang berharga dalam mengendalikan wabah virus flu burung. Vaksin pembunuh adjuvan dapat memberikan respon humoral yang baik dan telah terbukti efektif dalam mencegah virus patogen flu burung ringan (mildly pathogenic avian influenza) dan virus flu burung yang sangat patogen (highly pathogenic avian influenza). Virus HPAI sangat mematikan untuk unggas dan dapat menyebabkan wabah besar yang berdampak pada kerugian ekonomi Negara dan menyebar langsung dari unggas ke manusia dan merupakan ancaman pandemik bagi populasi manusia (Enawati, 2011; Suarez, 2000; Alexander, 2000).

WHO merekomendasikan upaya pencegahan untuk orang-orang yang mempunyai risiko tinggi kontak dengan unggas atau orang yang terinfeksi, dapat diberikan terapi profilaksis dengan $75 \mathrm{mg}$ oseltamivir sekali sehari, selama 7 sampai 10 hari (WHO, 2012). Beberapa hal penting yang patut diperhatikan untuk mencegah semakin meluasnya infeksi $\mathrm{H} 5 \mathrm{~N} 1$ pada manusia selain terapi profilaksis adalah dengan menjaga kesehatan diri dan lingkungan, dimana menjaga kesehatan diri dilakukan dengan meningkatkan imunitas tubuh (Radji, 2006).

Panax ginseng C.A. Meyer adalah salah satu tanaman obat hebat tradisional yang telah digunakan di seluruh dunia dengan berbagai manfaat yaitu untuk mengatasi kelelahan, meningkatkan seksualitas, antioksidan, anti tumor, immunomodulator, dan lain-lain. Panax ginseng mengandung beberapa komponen yaitu tetracyclic triterpenoid saponins (ginsenosides), polyacetylenes, polyphenoli, dan polysaccharides (Soowon, 2012).

Beberapa penelitian menyebutkan bahwa komponen polisakarida dalam Panax ginseng memiliki peran sebagai immunomodulator. Akar, batang, daun dari Panax ginseng dan ekstraknya telah banyak digunakan untuk menjaga homeostasis imun dan menjaga tubuh dari resistensi akibat penyakit atau serangan mikrobial yang berdampak pada sistem imun tubuh (Soowon, 2012; Park, 2013). 
Oleh karena itu, pada artikel ini akan membahas mengenai pengaruh polisakarida dalam Panax ginseng untuk vaksinasi flu burung (H5N1).

\section{METODE}

Metode yang digunakan dalam penulisan artikel ini adalah tinjauan literatur (literature review) terhadap teori-teori yang relevan baik internasional maupun nasional. Sumber tinjauan meliputi studi pencarian sistematis yang dilakukan menggunakan Elsevier, EBSCO, NCBI, dan Google cendekia sehingga didapatkan dalam jumlah 15 artikel.

\section{HASIL DAN PEMBAHASAN}

Panax ginseng termasuk dalam keluarga Araliaceae dan ditemukan di seluruh Asia Timur dan Rusia. Panax ginseng merupakan tanaman obat herbal tradisional yang memiliki banyak manfaat dan telah digunakan sejak bertahun-tahun lalu. Terdapat dua bentuk berbeda dari Panax ginseng, yaitu ginseng merah dan ginseng putih dan terdiri dari akar, batang dan daun (Park, 2013; Thome, 2009).

Panax ginseng telah banyak digunakan sebagai immuno-modulator (meningkatkan respon imun tubuh), meningkatkan memori dan kekuatan fisik tubuh, meningkatkan seksualitas, mengatasi kelelahan, antioksidan, antitumor, dan mempunyai efek terhadap sistem saraf pusat, kardiovaskular, endokrin, dan sistem imun tubuh (Soowon, 2012; Park, 2013).

Panax ginseng mengandung beberapa komponen yaitu ginsenoside, poliasetilen, polifenol, dan polisakarida. Ginsenoside dapat diklasifikasikan dalam 3 grup berdasarkan struktur kimia dari aglikon yaitu antara lain: (1) grup protopanaxadiol (e.g., Rb1, Rb2, Rb3, Rc, and Rd); (2) grup protopanaxatriol (e.g., Re, Rf, Rg1, and Rg2); (3) grup oleanane (e.g., Ro) (Soowon, 2012; Baek, 2012).

Beberapa penelitian menyebutkan bahwa polisakarida dalam Panax ginseng memiliki fungsi sebagai imunomodulator. Imunomodulator adalah senyawa yang mengubah aktivitas sistem imun tubuh dengan dinaminasi regulasi sel imun seperti sitokin. Cara kerja immunomodulator yaitu mengembalikan fungsi imun yang terganggu (imunorestorasi), menekan respon imun tubuh (imunosupresi) dan memperbaiki fungsi sistem imun (imunostimulasi). Imunomodulator digunakan pada penyakit infeksi, immunodefisiensi dan kanker (Puspitaningrum, 2015).

Berdasarkan hasil penelitian Auwalu dkk tahun 2016, polisakarida dalam Panax ginseng dapat meningkatkan respon imun tubuh ketika digunakan bersamaan dengan vaksin H5N1. Polisakarida sebagai immuno-modulator dapat menstimulasi produksi sitokin dan mengaktivasi makrofag sebagai upaya meningkatkan imun tubuh dalam melawan agen-agen yang menimbulkan penyakit salah satunya yaitu virus A influenza (Auwalu, 2016).

Hasil penelitian ini sesuai dengan penelitian yang dilakukan oleh Eun Hye Park dkk tahun 2014 yang mengatakan bahwa tikus yang diinduksi Ginseng dapat diproteksi dari virrus H5N1 yang dapat menyebabkan kematian. Penelitian tersebut menjelaskan bahwa Ginseng sangat berpontesi untuk melindungi manusia dari virus $\mathrm{H} 5 \mathrm{~N} 1$ sebagai vaksin karena fungsinya yang dapat meningkatkan respon imunitas tubuh (Park, 2013).

\section{SIMPULAN DAN SARAN}

Polisakarida dalam Panax ginseng sangat berpotensi sebagai vaksin virus H5N1 atau bahan tambahan dalam vaksin H5N1 karena dapat meningkatkan respon imunitas tubuh. 


\section{DAFTAR PUSTAKA}

Alexander D. J. and I. H. Brow (2000). Recent zoonoses caused by influenza A viruses. Revue Scientifiqueet Technique. 1(19):197-225. Retrieve from: https://www.ncbi.nlm.nih.gov/pubmed/11189716

Auwalu Y, Sanpha K, Xingang Yu, Yongliang Z, Gnuqing L. (2016). Vaccination with Astragalus and Ginseng Polysaccharides Improves Immune Response of Chickens against H5N1 Avian Influenza Virus. Reasearch Articel. BioMed Reasearch International 1(1): 1-8. Retrieve from: https://www.ncbi.nlm.nih.gov/pmc/articles/PMC5002477/pdf/BMRI2016-1510264

Baek SH, Bae ON, Park JH. (2012). Recent methodology in ginseng analysis. J Ginseng Res.36:119-134.

from: http://koreascience.or.kr/article/JAKO201212851254119.page

Ernawati R, Putranto E, Hanief M. (2011). Kandidat vaksin flu burung H5N1 bagi ternak ayam isolat asal Jawa Timur. Jurnal Ilmiah Kedokteran Hewan, 1(4):19-24. Retrieve from: http://journal.unair.ac.id/downloadfull/VetMed5851-49ffea6clefullabstract.pdf

Fauquet CM, Mayo MA, Maniloff J, Desselberger U dan Ball LA. (eds). (2005).Virus taxonomy: classification and nomenclature of viruses: eight report of the International Committee on the taxonomy of viruses. San diego: Elsevier Academic Press. Retrieve from: https://www.ncbi.nlm.nih.gov/pmc/articles/PMC1208960/

Janovie A, Rusdi, Supiyani A. (2014). Uji efektivitas vaksin flu burung subtipe H5N1 pada ayam kampung di Legok, Tangerang, Banten. Jurnal BIOMA, 2(10):35-40. Retrieve from: http://journal.unj.ac.id/unj/index.php/bioma/article/view/462

Park EH, Yum J, Ku KB, Kim HM, Kang YM. (2013). Red ginseng-containing diet helps to protect mice and ferrets from the lethal infection by highly pathogenic H5N1 influenza virus. Journal Of Ginseng Research. 1(38):40-46. Retrieve from: https://www.ncbi.nlm.nih.gov/pubmed/24558309

Puspitaningrum I, Kusmita I, Franyoto Y. (2015). Aktivitas Imunomodulator Fraksi Etil Asetat Daun Som Jawa (Talinum triangulare (Jacq.) Willd) Terhadap Respon Imun Non Spesifik. Jurnal Media Neliti.1(1): 24-29. Retrieve from: https://www.neliti.com/publications/101337/aktivitas-imunomodulator-fraksi-etil-asetatdaun-som-jawa-talinum-triangulare-ja

Radji, Maksum. (2006). Avian influenza A (H5N1): Patogenesis, pencegahan dan penyebaran pada manusia. Jurnal Ilmu Kefarmasian.2(3): 55-65. Retrieve from: http://psr.ui.ac.id/index.php/journal/article/view/3399

Smith GJ, Naipospos TSP, Nguyen TD, De Jong MD, Vijaikrisnha D, Usman TB, Hassan SS, Nguyen TV, Dao TV, Bui NA, Leung YLC, Cheung CL, Rayner, Webster RG, Chen H, Peiris JSM, Yuan G. (2006). Evolution and adaptation of H5N1 influenza virus in avian and human host in Indonesia and Vietnam. Jurnal Virology, 350:258-268. Retrieve from: https://www.ncbi.nlm.nih.gov/pubmed/16713612

Soowon K, Hyeyoung M. (2012). Ginseng, the 'Immunity Boost': The effects of Panax ginseng on immune system. Journal Of Ginseng Research. 4(36):354-368. Retrieve from: https://www.ncbi.nlm.nih.gov/pmc/articles/PMC3659612/

Suarez D. L. and S. Schultz-Cherry. (2000). Immunology of avian influenza virus. Developmental and Comparative Immunology. 2(4):269-283. Retrieve from: https://www.ncbi.nlm.nih.gov/pubmed/10717293 
Helm S. (2004). Cancer prevention and therapeutics: Panax ginseng.14(2):172-176. Retrieve from: https://www.ncbi.nlm.nih.gov/pubmed/15387718

World Health Organization. (2005). Evolution of H5N1 avian Influenza viruses in Asia. Emerg Infect Dis 11:15151521. Retrieve from: https://www.who.int/influenza/human_animal_interface/avian_influenza/h5n12011_08_30/en/

World Health Organization. (2012). H5N1 Avian influenza: Timeline of Major Events 11 Januari 2012. 
Wellness and Healthy Magazine, 2(1), February 2020, - 54

Geri Indra Herlambang 